\title{
COMPARTIMENTAÇÃO GEOMORFOLÓGICA DOS PLANALTOS ESCALONADOS DO SUDESTE DE MINAS GERAIS - BRASIL
}

\section{GEOMORPHOLOGICAL SUBDIVISION OF THE STAGGERED PLATEAUS IN SOUTHEAST MINAS GERAIS - BRAZIL}

\author{
Breno Ribeiro Marent \\ Departamento de Geografia, Universidade Federal de Minas Gerais \\ Av. Antônio Carlos, 6.627, Belo Horizonte, Minas Gerais ,CEP: 31270-901, Brasil \\ E-Mail: brenomarent@gmail.com \\ Roberto Célio Valadão \\ Departamento de Geografia, Universidade Federal de Minas Gerais \\ Av. Antônio Carlos, 6.627, Belo Horizonte, Minas Gerais, CEP: 31270-901, Brasil \\ E-mail:valadao@ufmg.br
}

\section{Informações sobre o Artigo}

Data de Recebimento:

26/11/2014

Data de Aprovação:

05/04/2015

\section{Palavras-chave:}

Anomalias de Drenagem;

Denudação Diferencial;

Retração de Escarpas.

\section{Keywords:}

Anomalies Drainage;

Differential Denudation;

Retraction of Scarps.

\section{Resumo:}

Na macroconfiguração geomorfológica do sudeste de Minas Gerais é notória a organização dos planaltos, em planta e perfil, segundo degraus escalonados. A delimitação espacial desses degraus coincide com a organização da rede hidrográfica regional, composta por grandes bacias interiores (Paraná e São Francisco) e por bacias costeiras menores (Doce e Paraíba do Sul). Esses agrupamentos de bacias são separados por um grande escarpamento, herança dos processos que colimaram na abertura mesocenozoica do Atlântico Sul. A compartimentação geomorfológica desses planaltos comprova o papel fundamental exercido pelo arcabouço litoestrutural na evolução e configuração da paisagem, bem como revela a participação de uma tectônica recente (cenozoica). As análises efetivadas neste trabalho se fundamentam no desnivelamento altimétrico que vigora na organização do relevo regional, à conta de remanescentes de blocos tectonizados e associados à diversidade litoestrutural. Os mapeamentos realizados comprovam a existência de três macrocompartimentos geomorfológicos, cuja morfologia regional manifesta caimentos topográficos em dois sentidos principais: para NW, nos degraus Paraná - São Francisco e Doce; para SE, no degrau Paraíba do Sul. Na morfogênese desses degraus foi fundamental o processo de retração denudacional das escarpas que, em múltiplas dimensões espaço-temporais, se articulou a condicionantes tectônicos e estruturais. As diferenças na dissecação das bacias costeiras indicam a atuação de níveis de base locais e uma resposta à orientação de estruturas regionais. As estruturas impõem um controle regional 
sobre a evolução da rede de drenagem com direção preferencial NE-SW. Anomalias de drenagem se encontram associadas ao controle litoestrutural e implicaram na reorganização da rede hidrográfica.

\begin{abstract}
:
In the geomorphological macro configuration of southeastern Minas Gerais - Brazil, the organization of plateaus, plan and profile, according staggered steps is notorious. The spatial delimitation of these steps coincide with the organization of regional hydrographic networks composed of large inland river basins (Paraná and São Francisco) and smaller coastal basins (Doce and Paraíba do Sul). These river basins groups are separated by a great escarpment derived from the processes that culminated in the meso-cenozoic opening in the South Atlantic. The geomorphological subdivision of these plateaus confirms the fundamental role played by the litostructural framework in evolution and landscape configuration, revealing the participation of a recent tectonic (Cenozoic). Analyses in this study were based on altimetry unevenness that prevails in the regional terrain relief organization, the remaining account of tectonized blocks, and associated litostructural diversity. The mappings carried out prove the existence of three geomorphological macrocompartiments, whose regional morphology shows topographic trims in two main directions: NW, in Paraná steps - San Francisco and Doce; towards SE in the Paraíba do Sul step. In the morphogenesis of these steps, the denudational retraction process of the escarpment that in multiple spatial and temporal dimensions, articulated the tectonic and structural constraints was fundamental. The differences in the dissection of coastal basins indicate the performance of local background levels and a response to the orientation of regional structures. The structures impose a regional control over the evolution of the drainage network with a preferential NE-SW direction. Drainage anomalies are associated with litostructural control and have resulted in the reorganization of the river system.
\end{abstract}

\section{Introdução}

O Brasil oriental abrange, do ponto de vista geomorfológico, um grande escarpamento que divide extensas bacias interioranas de bacias menores que ocupam posição costeira. Esse escarpamento tem sua gênese relacionada à tectônica mesocenozoica que afetou essa porção do território brasileiro (ALMEIDA, 1976; VALADÃO, 1998; ZALÁN; OLIVEIRA, 2005). Demais áreas do planeta marcadas pela ocorrência de semelhante configuração geomorfológica apresentam, também, uma drenagem dual típica de margens passivas de grande elevação (GILCHRIST; SUMMERFIELD, 1990; OLLIER; PAIN, 1997; VALADÃO, 1998; MATMON et al., 2002; GUNNELL; HARBOR, 2010; MARENT et al., 2013).

É nesse contexto que se inserem os planaltos escalonados do sudeste de Minas Gerais e parte das bacias hidrográficas do Paraná, São Francisco, Doce e Paraíba do Sul. Nesses planaltos há uma configuração geomorfológica regional em degraus que coincide com a organização da rede hidrográfica. As grandes bacias do São Francisco e Paraná drenam em direção ao interior continental e integram um mesmo degrau, ao passo que as bacias menores do Doce e do Paraíba do Sul constituem degraus distintos que drenam diretamente para o oceano (Figura 1).

Segundo Valadão (1998) o nível de base altimetricamente mais baixo em um dos lados desse grande escarpamento comanda sua evolução, marcada por taxas de denudação mais elevadas na porção altimetricamente mais rebaixada. Sabe-se que a litoestrutura também exerce importante controle sobre a evolução de redes de drenagem e na fixação de divisores hidrográficos (GILCHRIST et al., 1994; VAN DER BEEK et al., 2002; GUNNEL; HARBOR, 2010). De acordo com Ferreira (2001) a compartimentação geomorfológica permite identificar o controle da litologia e estrutura na evolução da paisagem, além de indicar características tectônicas. Dessa forma, o objetivo desse trabalho foi mapear esses compartimentos e analisar a resposta geomorfológica deles segundo condicionantes litoestruturais, bem como investigar a relação entre o arranjo espacial dos degraus e a rede hidrográfica, em planta e perfil.

A área de estudo situa-se no sudeste do Estado de Minas Gerais (Brasil), a sul do Quadrilátero Ferrífero, entre os paralelos $20^{\circ} 35^{\prime}$ e $21^{\circ} 35^{\prime} \mathrm{S}$ e meridianos $42^{\circ}$ $30^{\prime}$ e $44^{\circ} 15^{\prime} \mathrm{W}$ (Figura 2). É representada pela bacia do alto rio Paraopeba no rio São Francisco, bacia do alto rio Grande no rio Paraná, bacia do alto rio Doce e bacia do rio Pomba no rio Paraíba do Sul. Os litotipos da área de estudo são aqueles formados em grande parte por complexos basais metamórficos, coberturas metassedimentares do Supergrupo Rio das Velhas e Grupo São João Del Rei e por uma diversidade de corpos intrusivos de composição litológica variada (Figura 3) (ALKMIM, 2004). 


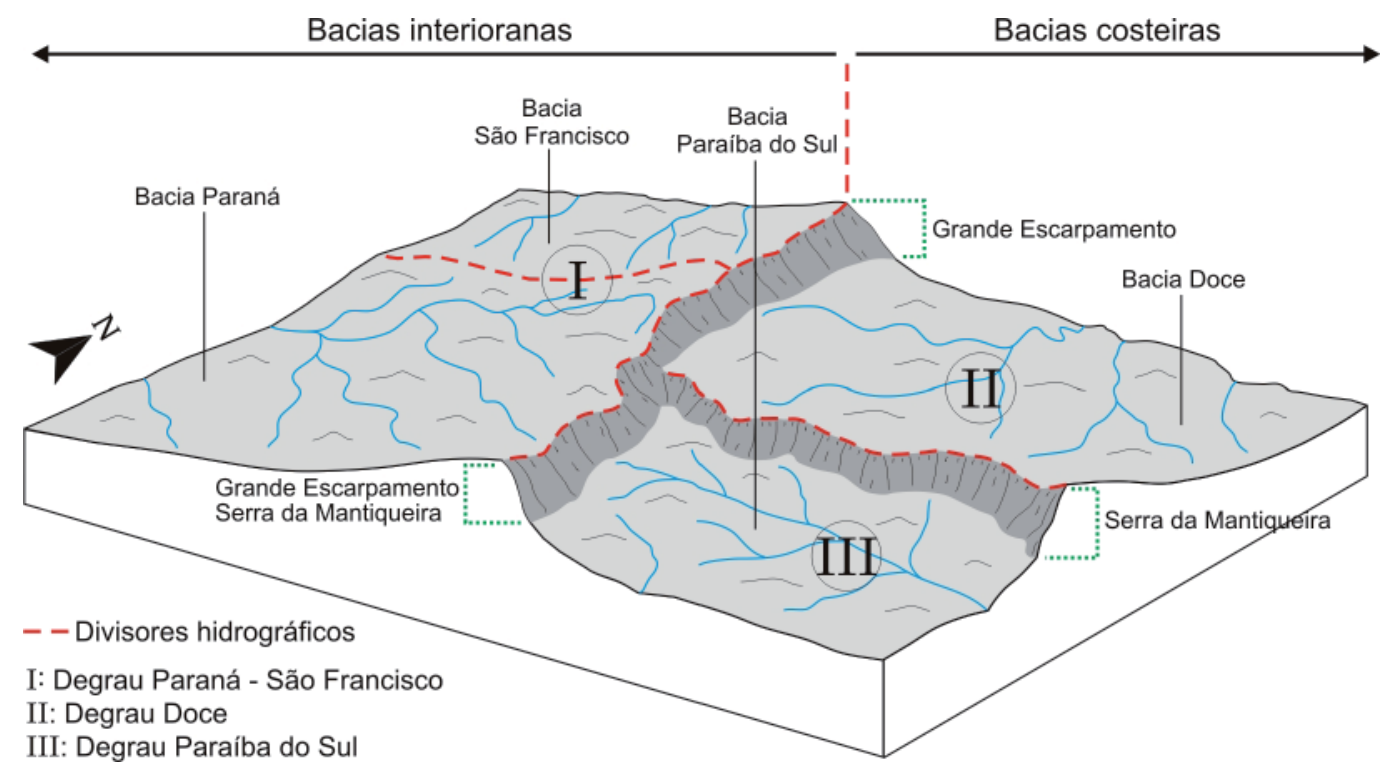

Figura 1 - Representação esquemática da configuração dos degraus escalonados e bacias hidrográficas no sudeste de Minas Gerais.

\section{Materiais e Métodos}

A execução deste trabalho teve início na consulta de dados e informações disponíveis em mapas e cartas, apoiando-se, também, na literatura geológica e geomorfológica da área investigada. A associação de ambas fundamenta os procedimentos teórico-metodológicos aqui adotados. Investigações de campo subsidiaram a definição dos limites estabelecidos para os compartimentos geomorfológicos reconhecidos e mapeados em gabinete. O material cartográfico constou da consulta a diferentes temas e espacialidades: (i) mapas e cartas geológicas nas escalas 1:1.000.000, 1:250.000 e 100.000; (ii) cartas topográficas digitalizadas do IBGE na escala 1:50.000; e (iii) imagens de satélite de alta resolução do GoogleEarth. Esses possibilitaram a confecção de mapas geológico (Figura 3), de elevação digital do terreno (MDE) (Figuras 5 e 10), hipsométrico (Figuras 5 e 10), de compartimentação geomorfológica (Figura 4) e de lineamentos estruturais (Figura 14). Com base nas cartas topográficas foram produzidas seções altimétricas regionais que evidenciam a organização topográfica e a relaciona ao arcabouço litoestrutural regional (Figuras 6, 7, 8, 9, 12 e 13), obtido do mapa geológico em escala 1:1.000.000. Através de MDE foi gerado sombreamento

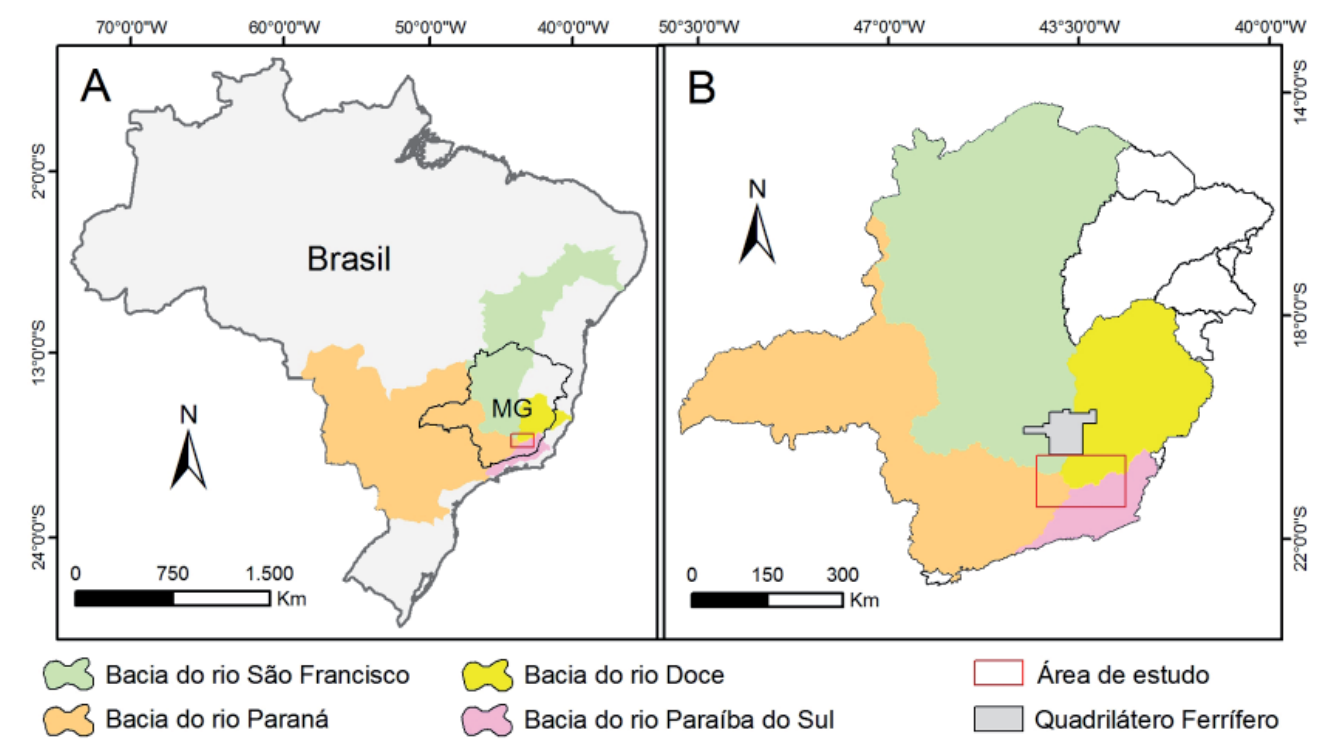

Figura 2 - Localização da área de estudo no Brasil (A) e no Estado de Minas Gerais (B). 
do relevo com iluminações de azimutes $45^{\circ}, 315^{\circ}$ e $360^{\circ}$, sendo posteriormente traçados os lineamentos de cristas e fundos de vale. Esses foram utilizados para geração da frequência absoluta (FA) e comprimento absoluto (CA) no digrama de rosetas do software Spring 5.2.5.

Os procedimentos para identificação e análise dos compartimentos geomorfológicos se basearam em adaptações dos trabalhos de Meis et al. (1982), Saadi (1991), Ferreira (2001) e Silva (2002). O critério para delimitação se baseou no desnivelamento altimétrico que, segundo Meis et al. (1982), identifica as grandes feições do relevo remanescentes de blocos tectonizados e/ou associados à variação litoestrutural, bem como da análise de MDE. A análise foi realizada por meio da associação da compartimentação do relevo com as características litoestruturais, de modo a apresentar subsídios voltados para discussão de sua evolução. As características estruturais foram avaliadas ainda segundo o mapa de lineamentos. Os compartimentos foram subdivididos em unidades menores, com os desníveis diferenciados em escarpa mais baixa, intermediária e mais elevada, conforme proposto por Saadi (1991), sendo respectivamente expressas nas amplitudes médias inferiores a $250 \mathrm{~m}$, entre 250 e $500 \mathrm{~m}$ e superiores a $500 \mathrm{~m}$.

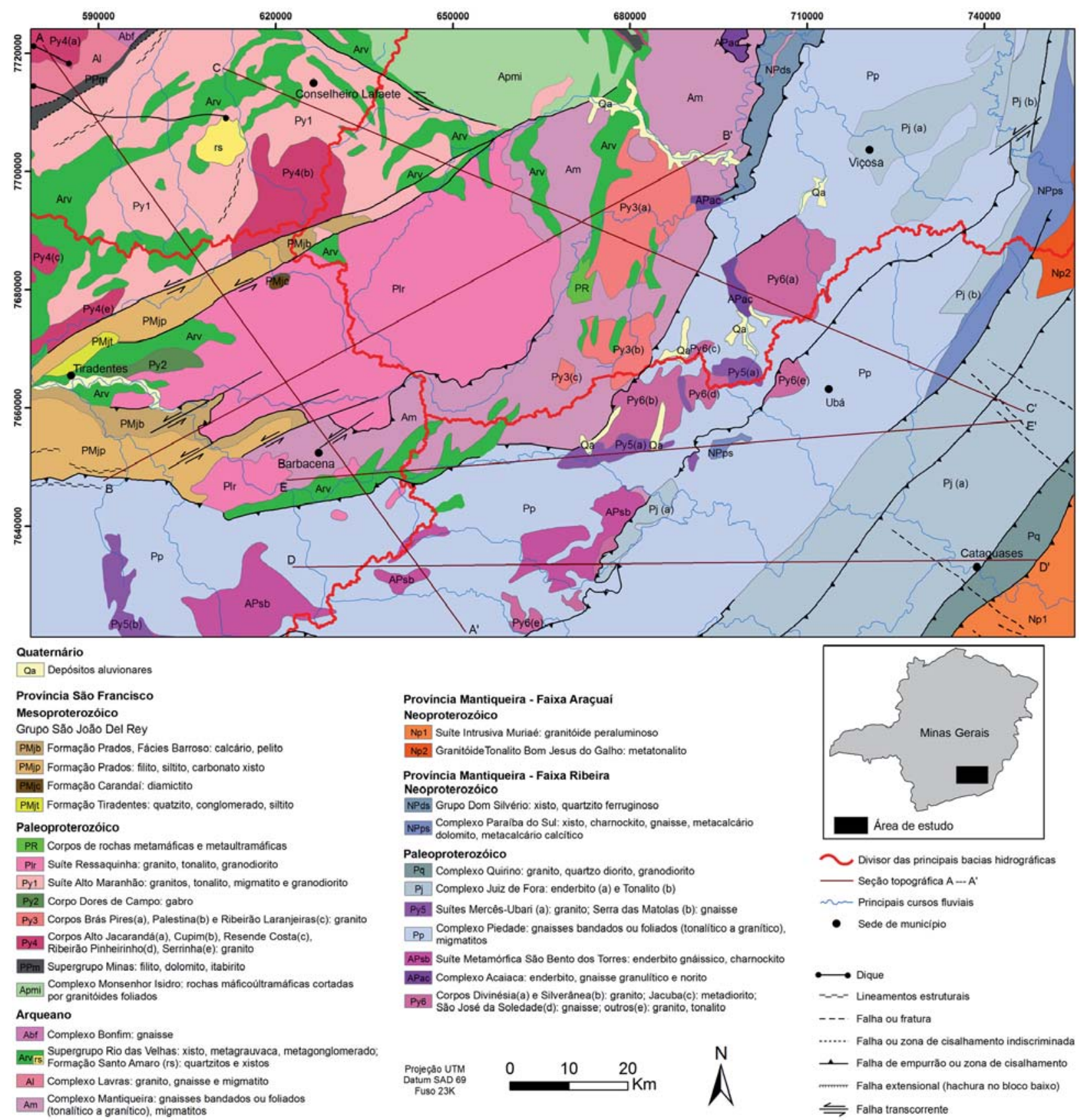

Figura 3 - Geologia do sudeste de Minas Gerais, adaptada de Heineck et al. (2003). Observar no mapa a localização das seções topográficas regionais descritas no texto. 


\section{Compartimentação Geomorfológica dos Planaltos Escalonados do Sudeste de Minas Gerais}

\section{Resultados e Discussões}

A compartimentação geomorfológica da área de estudo, na escala analisada, é relativamente simples, embora as feições apresentem maior grau de heterogeneidade quando analisadas em maior detalhe. Amorfologia regional étípica de relevo em degraus escalonados que se mostram muito bem marcados na paisagem, os quais exibem uma face escarpada de um lado e, de outro, superfície planáltica com caimento suave em direção ao interior das bacias hidrográficas do Paraná, Doce e São Francisco.

A diferenciação dos compartimentos geomorfológicos é comandada por fatores litoestruturais que, em última análise, possibilitaram diferentes graus de dissecação do relevo. O produto dessa dissecação, que atuou sobre o arcabouço geológico pré-cambriano (Figura 3), deu origem a subcompartimentos que se relacionam a cada bacia hidrográfica/degrau. As escarpas que delimitam esses degraus possuem orientação principal NW, NE, NNE e ENE e estão associadas aos divisores das bacias hidrográficas Paraná - São Francisco, Doce e Paraíba do Sul.

Considerando os fatores geológicos e a diferenciação entre a dissecação do relevo e a amplitude topográfica, foram identificados três compartimentos associados às bacias hidrográficas (Figura 4): (i) Degrau Paraná - São Francisco; (ii) Degrau Doce; e (iii) Degrau Paraíba do Sul. Cada degrau foi subdividido em unidades que podem corresponder a planaltos, serras e depressões. A seguir são descritas e discutidas as principais características geológico-geomorfológicas de cada uma dessas unidades.

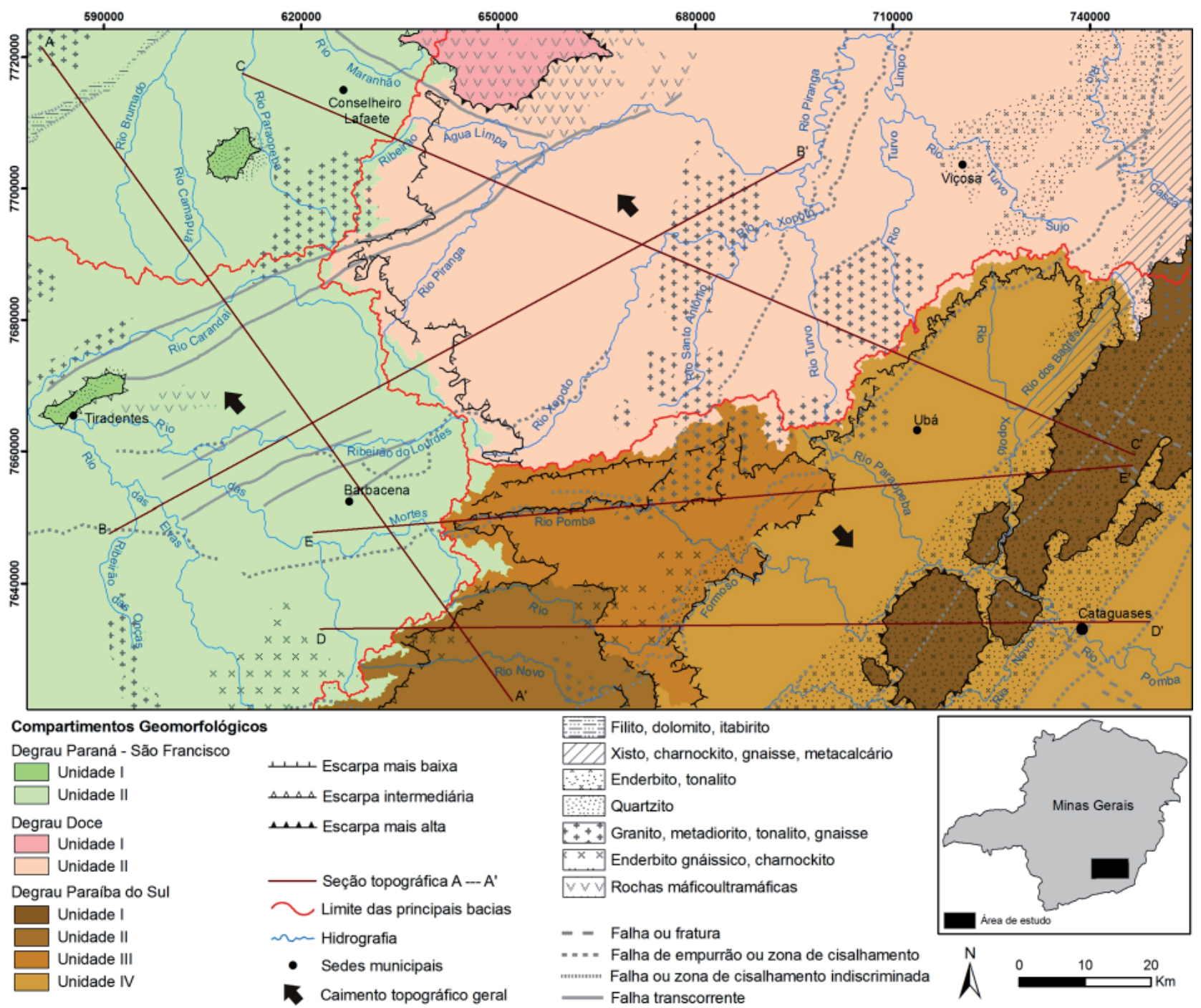

Figura 4 - Compartimentação geomorfológica do sudeste de Minas Gerais. As seções topográficas regionais localizadas no mapa são descritas no texto e destacam alguns elementos geológicos de interesse para a análise morfoestrutural. 


\subsection{Degrau Paraná - São Francisco}

Esse compartimento corresponde, quase em sua totalidade, às bacias dos rios São Francisco e Paraná, que drenam em direção ao interior continental. Distinguem-se dos compartimentos geomorfológicos adjacentes situados a leste pela presença de escarpas intermediárias, em geral com mais de $250 \mathrm{~m}$ de altura. Subdivide-se em duas unidades que se individualizam segundo aspectos morfológicos e litoestruturais.

\subsubsection{Unidade I - Degrau Paraná - São Francisco}

Destaca-se em relação ao seu entorno em razão da ocorrência de serras isoladas. É condicionada predominantemente pela denudação diferencial entre quartzitos e demais rochas do entorno, sendo compreendida por duas serras: uma na bacia do São Francisco e outra na bacia do Paraná. Na bacia do São Francisco se destaca a Serra da Caixeta, com altitudes que variam dos 920 a 1440m, constituída predominantemente por quartzitos da Formação Santo Amaro (Supergrupo Rio das Velhas)
(Figuras 4). Na bacia do Paraná se destaca a Serra de São José, com altitudes que variam dos 900 a 1420m, modelada predominantemente em quartzitos da Formação Tiradentes (Grupo São João Del Rey).

\subsubsection{Unidade II - Degrau Paraná - São Francisco}

Essa unidade possui altitudes em torno de 1220m nas porções mais elevadas da bacia do rio Paraná, exibindo decréscimo para 1180m na bacia do São Francisco nas bordas desse degrau (Figura 5). A NW, nas porções mais baixas, o decréscimo da altitude chega a $900 \mathrm{~m}$ na bacia do Paraná e 860m na bacia do São Francisco. Essas bacias são separadas por um baixo degrau (Figura 4) que varia de 80 a $220 \mathrm{~m}$ de altura, porém, não se trata de um escarpamento, pois o seu modelado é suave e, no campo, de difícil reconhecimento. Segundo Gatto et al. (1983) sobressaem formas mamelonares e de cristas, o que resulta numa paisagem característica do tipo "mar de morros” e, em menor proporção, ocorrem colinas com topos convexos a tabulares.

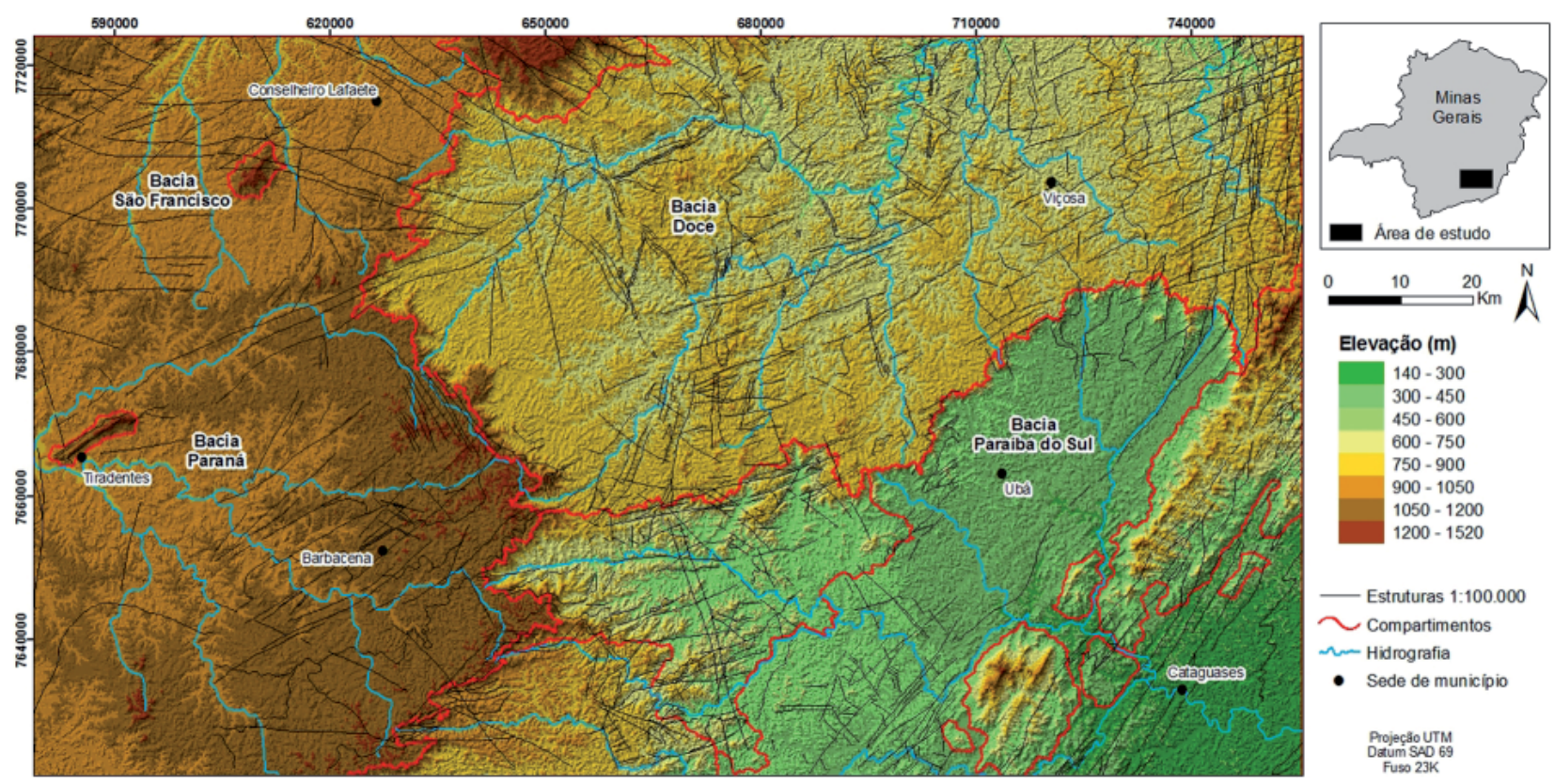

Figura 5 - Limite dos compartimentos geomorfológicos do sudeste de Minas Gerais em MDE com hipsometria, que contempla estruturas geológicas obtidas na escala 1:100.000.

A Suíte Metamórfica São Bento dos Torres e o granito Cupim (Py4) indicam uma influência na manutenção da escarpa ao longo dos divisores hidrográficos (Figuras 3 e 6). A diversidade topográfica verificada ao longo do divisor da bacia do rio Paraná com o Doce (Figura 7) sugere ocorrência de litologias de resistência diferenciada na Suíte Ressaquinha (Plr). Apesar de alguns desses litotipos abrangerem porções dos divisores não se identificou um condicionamento de expressão regional dos mesmos. O controle litológico sobre a topografia também pode ser evidenciado na bacia do rio São Francisco (Figura 8). Unidades litológicas de 


\section{Compartimentação Geomorfológica dos Planaltos Escalonados do Sudeste de Minas Gerais}

diferentes resistências (Figuras 3) promovem variações no modelado a NW (Figura 8) contrastando com a porção SE, que exibe uma única unidade litológica (Suíte Alto Maranhão).

As estruturas exibem direções predominantemente NE-SW (Figura 3), com maior destaque para duas falhas transcorrentes que se prolongam a NE, fechando-se na Unidade II - Degrau Doce, coincidindo com a Descontinuidade Crustal do Alto Rio Grande. Essa unidade indica um comportamento estrutural diferenciado entre dois domínios geotectônicos. No Cráton do São Francisco, situado a norte da Descontinuidade Crustal do Alto Rio Grande, predominam as direções NW-SE e E-W a WNW-ESE, enquanto na Província Mantiqueira, a sul, a direção NE-SW (Figura 5). No contexto regional, não foi identificada qualquer estrutura que pudesse estar associada à escarpa desse degrau. Entretanto, foi identificado feixe de falhas de direção NW-SE no vale suspenso do rio Piranga que o condiciona estruturalmente (Figuras 4 e 5).

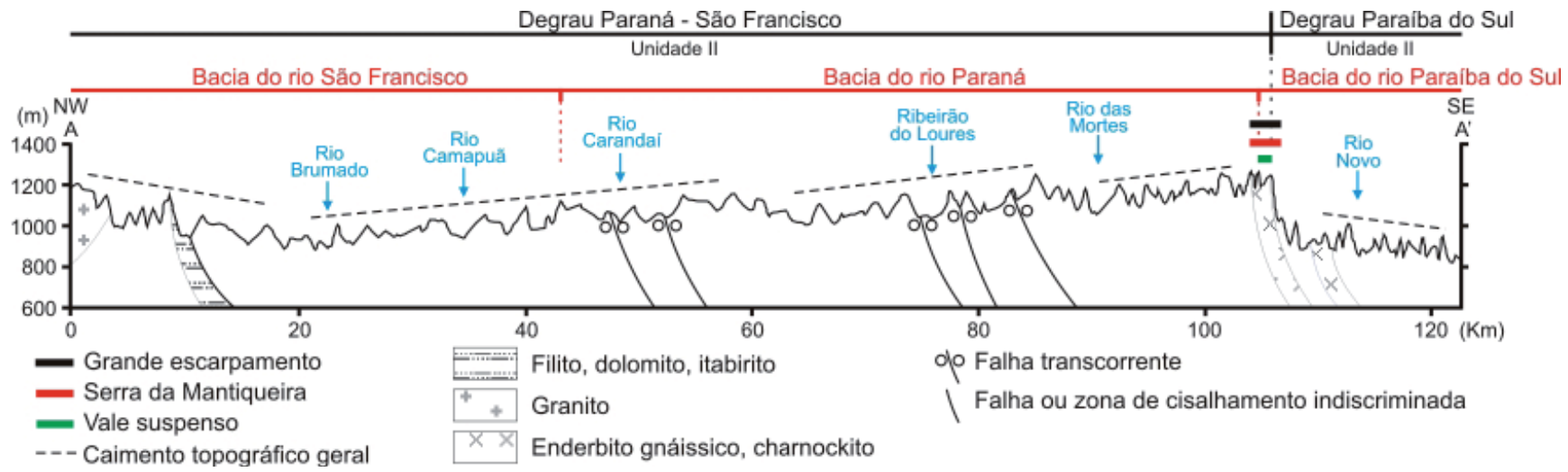

Figura 6 - Seção topográfica regional A-A', em que se reconhecem os degraus Paraná - São Francisco e Paraíba do Sul.

As bacias dos rios Paraná e São Francisco na área de estudo compõem um extenso degrau com caimento geral de SE para NW (Figuras 6e 8). Degraus menores também apresentam caimento na mesma direção. Esses, segundo Saadi (1991), correspondem ao falhamento da escarpa da Serra da Mantiqueira que induziu ao basculamento generalizado da bacia do alto rio Grande (Rio Paraná) e atingiu o interior do estado entre o final do Mioceno e o Plioceno, com atuação até o Quaternário. Entretanto, na porção NW desse compartimento, o caimento do relevo está associado ao controle litológico. Os litotipos presentes no corpo intrusivo Alto Jacarandá e no Supergrupo Minas se sobrepõem aos condicionantes tectônicos, o que impõe caimento para SE (Figuras 3 e 6).

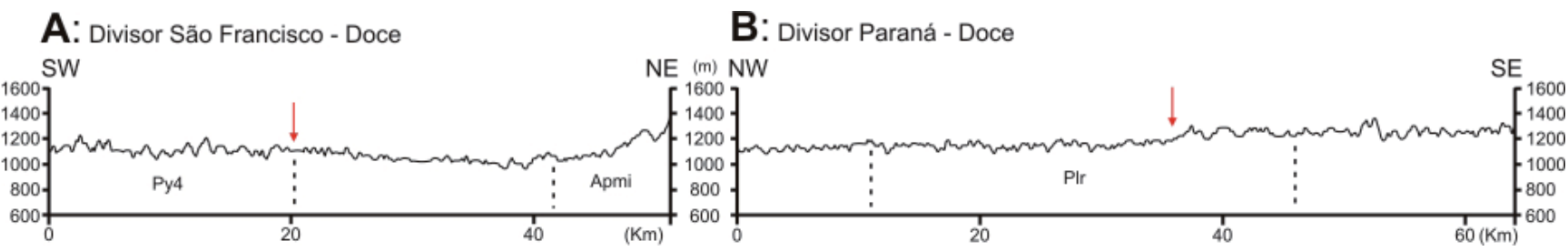

Figura 7 - Seções topográficas ao longo dos divisores hidrográficos que separam as bacias dos rios São Francisco - Doce (A) e Paraná Doce (B). A linha tracejada representa mudança de litologia, porém sem indicação de mergulho. As setas indicam mudanças na organização da topografia ao longo da seção.

Vales suspensos ocorrem em toda a borda do Degrau Paraná - São Francisco (Figuras 4, 6, 8 e 9), podendo ser identificadas inflexões de drenagem, a exemplo daquelas dos rios Piranga, Água Limpa e Xopotó. Algumas dessas inflexões foram constatadas como feições relacionadas a capturas fluviais por Cherem et al. (2013). Nesse sentido, as inflexões dos rios das Mortes e Carandaí, localizadas nas proximidades de cabeceiras, sugerem ocorrências anômalas do recuo da escarpa. Em alguns trechos mais recuados 
Marent B. R. \& Valadão R. C.

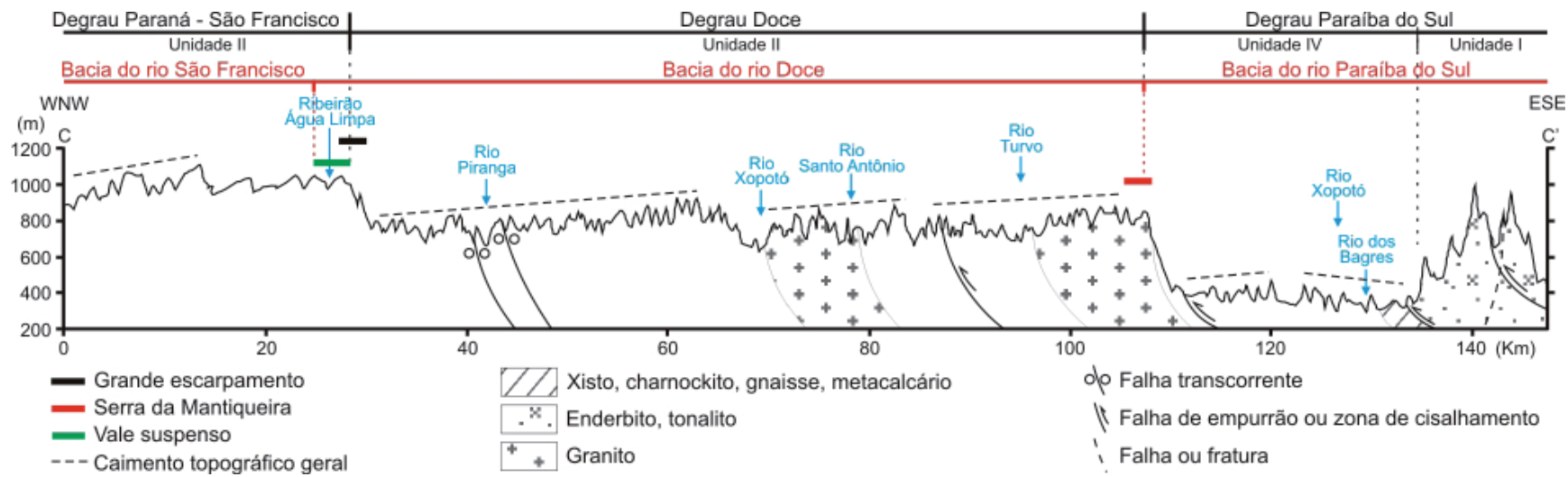

Figura 8 - Seção topográfica regional C-C’, em que se reconhecem os degraus Paraná - São Francisco, Doce e Paraíba do Sul.

essas escarpas coincidem com o divisor, onde não há ocorrência de vales suspensos. Os rios das Onças e das Elvas também exibem anomalias ao se alinharem em direção NNW-SSE e apresentarem trechos retilíneos em suas cabeceiras sobre os granitoides, ao mesmo tempo em que mudam de direção para oeste segundo brusca inflexão estruturalmente controlada (Figura 3).

\subsection{Degrau Doce}

Corresponde a um compartimento intermediário situado predominantemente abaixo do Degrau Paraná - São Francisco e acima do Paraíba do Sul. A exceção é para a Unidade I - Degrau Doce que se situa acima do Degrau Paraná - São Francisco. A Unidade II é a mais representativa dentro desse compartimento, estabelece contato com o Degrau Paraíba do Sul e Paraná - São Francisco e, por essa razão, compreende a unidade de maior interesse neste trabalho.

\subsubsection{Unidade I - Degrau Doce}

É uma unidade compreendida pelo Complexo Monsenhor Isidro, constituído por rochas máficas e ultramáficas (HEINECK et al. 2003) intimamente associadas a gnaisse tonalítico e trondhjemítico e bandas subordinadas de xisto, formação ferrífera e quartzito (RAPOSO, 1991) (Figuras 3 e 4). As altitudes máximas predominam em torno dos $1300 \mathrm{~m}$, chegando a $1420 \mathrm{~m}$ nas porções mais elevadas, sendo a face SE a mais escarpada, onde as altitudes normalmente ultrapassam os $500 \mathrm{~m}$. A porção norte possui caimento suave que termina próximo ao sopé da Serra de Ouro Branco, fora da área de estudo. A oeste é constituída por escarpas intermediárias que normalmente ultrapassam os $250 \mathrm{~m}$. Sua morfologia associada à litoestrutura sugere relevo proveniente da denudação diferencial com forte condicionante estrutural NW-SE e NNW-SSE associado a vales encaixados, que indicam o desmonte dessa unidade de SE para NW (Figura 5).

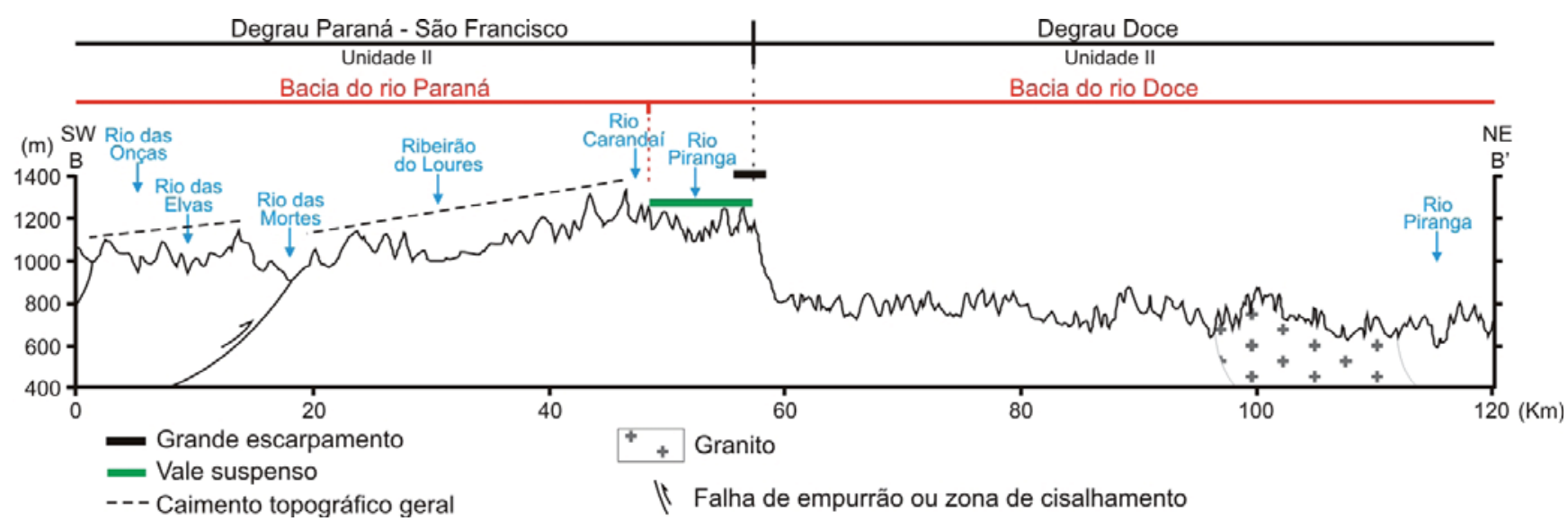

Figura 9 - Seção topográfica regional B-B’, em que se reconhecem os degraus Paraná - São Francisco e Doce. 


\subsubsection{Unidade II - Degrau Doce}

Na área de estudo essa unidade exibe altitudes de 800 a $900 \mathrm{~m}$ a SE na Serra da Mantiqueira, com um caimento topográfico a NW (Figura 8) que alcança os $600 \mathrm{~m}$ nas porções mais rebaixadas (Figura 10). No entanto, o predomínio é de altitudes entre 700 e $800 \mathrm{~m}$ nas porções mais baixas a NW. Esse caimento exibe ainda blocos menores com o mesmo sentido em altime- trias distintas (Figura 8). Nesse degrau, Souza (1995) identificou vários blocos basculados no sentido NW, na bacia do alto rio Doce, estruturados a partir de uma dinâmica pleistocênica. A oeste exibe escarpas com caimento gradativo da bacia do rio Paraná ( $400 \mathrm{~m})$ em direção a bacia do rio Doce ( 250m). Segundo Gatto et al. (1983) e Souza (1995) o modelado é marcado por vales encaixados e formas convexas que conferem aspecto de "mares de morros".

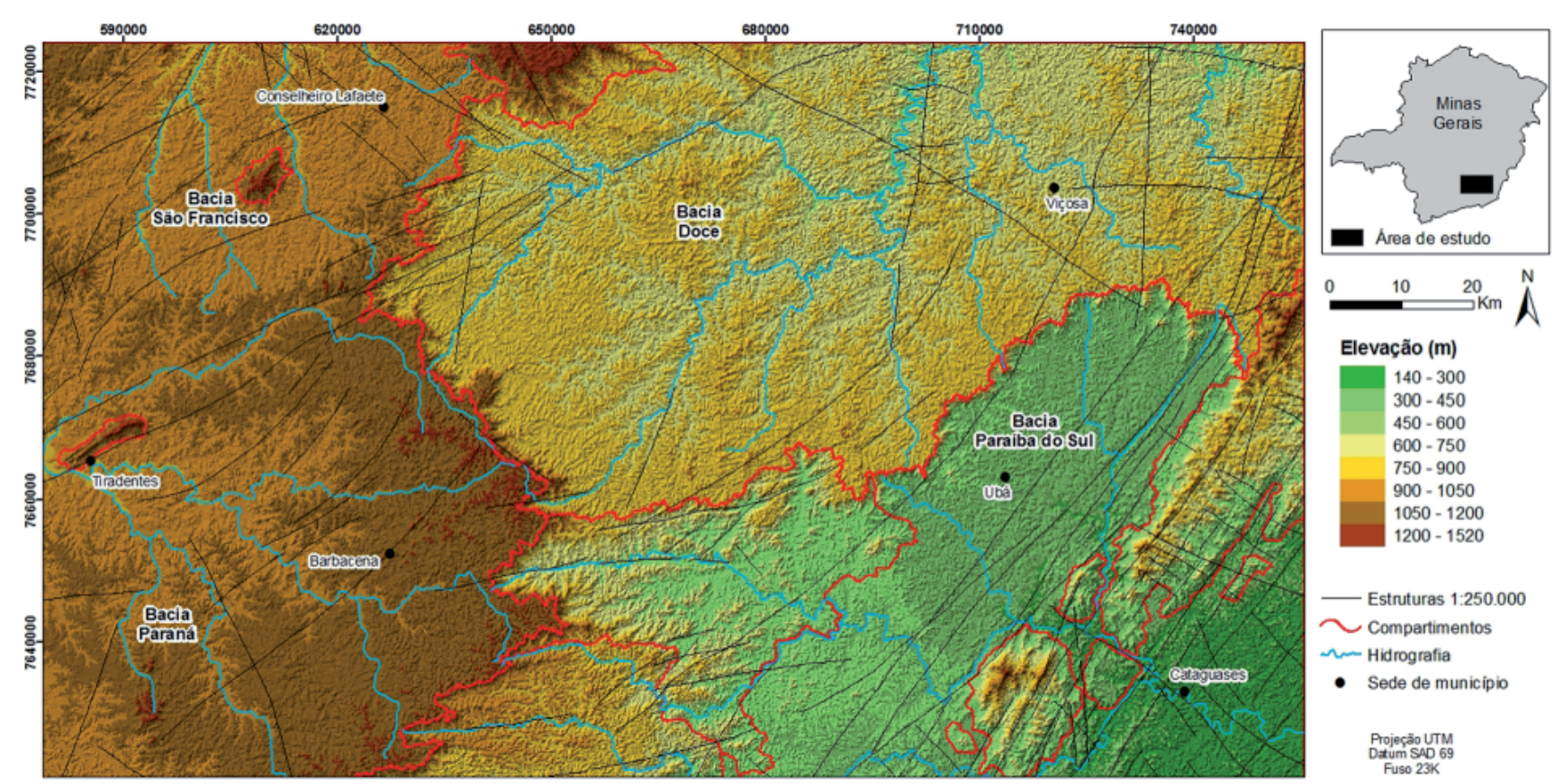

Figura 10 - Limite dos compartimentos geomorfológicos do sudeste de Minas Gerais em MDE com hipsometria, que contempla estruturas geológicas obtidas na escala 1:250.000.

Predominam nessa unidade estruturas NE-SW (Figura 3), destacando-se duas falhas transcorrentes paralelas que exibem um prolongamento da Descontinuidade Crustal do Alto Rio Grande (N60E). Ao longo do divisor Paraná - São Francisco com Doce as escarpas NE e NW se conectam nessas estruturas, formando uma concavidade no escarpamento e evidenciando um recuo mais intenso nesse local (Figura 4). Ao longo desses divisores as escarpas se revelam sinuosas com reentrâncias associadas a estruturas em diferentes escalas (Figuras 4, 6 e 10).

As principais drenagens são reveladoras do condicionamento estrutural regional. O rio Piranga assume direção NNE-SSW após entrar no Degrau Doce e, depois, a NE quando passa a ser condicionado pela Descontinuidade Crustal do Alto Rio Grande (Figura 4). À jusante, segundo Souza (1995), o curso fluvial escapa dessa descontinuidade e passa a se submeter ao controle de falhas recentes E-W. O rio Xopotó sugere um controle estrutural NNE-SSW, mudando para E-W em longitude próxima a inflexão do rio Piranga. O rio Xopotó, em seu baixo curso, apresenta brusca inflexão alinhada em arco com a migração de trechos do médio rio Turvo Limpo e médio Turvo Sujo, em direção NE -SW. Ao longo do rio Casca há um aumento expressivo de estruturas NNE-SSW e ENE-WSW, acompanhadas da imposição de um condicionamento recorrente desse curso nessas direções (Figuras 5 e 10). Outra anomalia identificada é a inflexão do rio dos Bagres (Figura 4) no vale suspenso do divisor com a bacia do Paraíba do Sul, constatada por Cherem et al. (2013) como decorrente de uma captura fluvial a partir da diferença de nível de base.

A influência da litologia sobre a configuração da escarpa parece ocorrer localmente através de corpos intrusivos que exibem a rocha sã com a frente escarpada, 
como no granito Divinésia (Figura 8) e granito Mercês -Ubari (Figura 3). A leste, sobre os complexos Juiz de Fora e Paraíba do Sul, a morfologia assume caráter de maior rugosidade no terreno com aumento da altitude. Nessa porção, as litologias associadas às estruturas são, ao que tudo indica, as responsáveis pelo relevo mais movimentado e elevado.

\subsection{Degrau Paraíba do Sul}

Esse compartimento constitui um degrau escalonado em vários níveis altimétricos com caimento topográfico geral a SE; é drenado por afluentes do baixo rio Paraíba do Sul, sendo o rio Pomba o principal deles. Esse degrau pode ser dividido em compartimentos menores, alguns apresentando também escalonamento, e estabelece limite com os degraus Doce e Paraná - São Francisco.

\subsubsection{Unidade I - Degrau Paraíba do Sul}

Constitui-se em um alinhamento de cristas com direção NE-SW (Figura 4) em que predominam altitudes entre 700 a $1000 \mathrm{~m}$, mas que podem alcançar $1537 \mathrm{~m}$. Seu relevo é bastante dissecado e exibe vales profundos e encaixados adaptados a estruturas NE-SW e NW-SE. Essa unidade foi denominada por Noce et al. (2003) de horst da Serra da Boa Vista (HSBV), sendo demarcada por um proeminente escarpamento em suas faces NW e SE. O rio Pomba corta essa unidade e forma uma garganta de direção NW-SE. Estruturas de mesma direção ocorrem acompanhando esse curso fluvial (Figura 10), sendo responsáveis pelo condicionamento estrutural desse canal durante seu processo de encaixamento.

A porção SE dessa unidade se encontra mais rebaixada em relação à NW e coincide com o predomínio de estruturas e revela sua influência na denudação e encaixamento dos vales (Figuras 4, 5 e 10). A orientação da foliação principal de acordo com Noce et al. (2003) exibe direção preferencial NE-SW, com mergulhos elevados de NW para SE. Em sua porção NW o relevo mais elevado se assemelha a um alinhamento NE-SW de pontões graníticos. Segundo Meis et al. (1982) a litologia charnockitica que compõem o alinhamento dessa unidade promove uma ruptura de declive entre o escalonamento a NW e SE da Unidade IV - Degrau Paraíba do Sul. Os charnockitos também são citados por
Noce et al. (2003) em associação com os enderbitos, compondo o embasamento do Complexo Juiz de Fora e sendo recobertos por paragnaisses da Megassequência Andrelândia na porção mais rebaixada. Entretanto, no contexto regional, segundo Heineck et al. (2003), o que predominam são enderbitos. Essa litologia parece exercer não só uma influência na formação de níveis de base, mas também na denudação diferencial que promove a manutenção do relevo escarpado.

O caimento topográfico geral dessa unidade ocorre de NW para SE e, consequentemente, contraria o sentido geral dos degraus Paraná - São Francisco e Doce, ocorrendo ainda blocos menores em seu interior. Noce et al. (2003) constataram a existência de diferentes níveis bauxíticos entre as cotas de 700 e $900 \mathrm{~m}$, que permitem inferir um basculamento e deslocamento de blocos de dimensões menores em seu interior. Mello et al. (2005) identificaram blocos abatidos, soerguidos e basculados a NW dessa unidade se estendendo até a Serra do Mar (Figura 11). Entretanto, mesmo que esse caimento seja resultado de tectônica recente, nota-se a influência estrutural e da dissecação mais acentuada na porção SE dessa unidade, bem como a litológica nos processos de denudação diferencial.

\subsubsection{Unidade II - Degrau Paraíba do Sul}

Essa unidade geomorfológica constitui um planalto nivelado aproximadamente em torno dos 900 a $950 \mathrm{~m}$ (Figuras 3 e 12). A escarpa a oeste pode chegar a 1220m e a leste a 550m, enquanto a norte existe uma elevação gradual da cota mais baixa para a mais elevada. É um relevo com morros de topos aguçados a convexos, que exibem caimento topográfico geral para SE (Figura 6).

Os cursos d'água exibem canais retilíneos e indicam um controle estrutural que resulta na formação de vales encaixados. Essas estruturas condicionam boa parte de seus cursos fluviais, sendo os principais rios (Formoso e Novo) com orientação E-W a ENE-WSW (Figura 4). Em escala de maior detalhe estruturas E-W, NE-SW e NW-SE se concentram nas porções leste e oeste, onde o relevo se apresenta mais dissecado (Figuras 5 e 10). Essas estruturas, uma vez associadas à litologia dos corpos intrusivos, impõem controle litoestrutural que condiciona a drenagem de E-W a ENE-WSW para NW-SE (Figuras 3 e 4). As estruturas exibem, ainda, associação com as reentrâncias e a elevada sinuosidade na escarpa a oeste. 


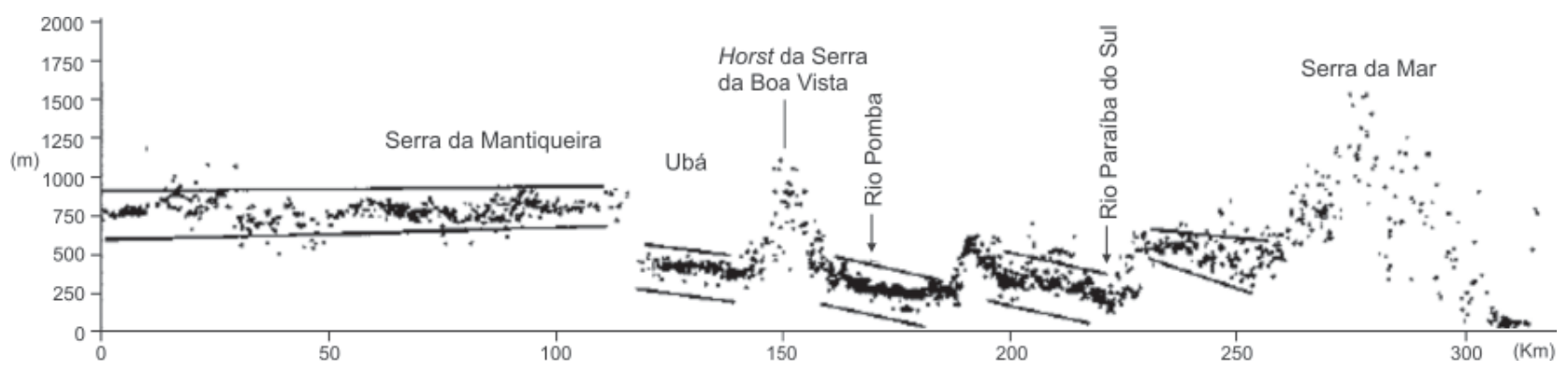

Figura 11 - Perfil topográfico em varredura, em que se destaca o escalonamento interno da depressão dos rios Pomba-Muriaé e o horst da Serra da Boa Vista. Fonte: adaptado de Mello et al. (2005).

Morales et al. (2014) identificaram entre essa unidade e a unidade III um lineamento neotectônico.

Litologias da Suíte Metamórfica São Bento dos Torres (enderbito gnáissico e charnockito) e outras rochas intrusivas (granito e tonalito) exercem influência na formação de níveis de base locais nos rios Novo e Formoso, sustentando esse planalto intermediário e impedindo dissecação mais intensa como no restante desse degrau (Figuras 3, 4 e 12). A oeste, no Degrau Paraná - São Francisco, vales suspensos adjacentes a cursos fluviais estruturalmente controlados podem ser identificados drenando em direção à bacia do Paraíba do Sul.

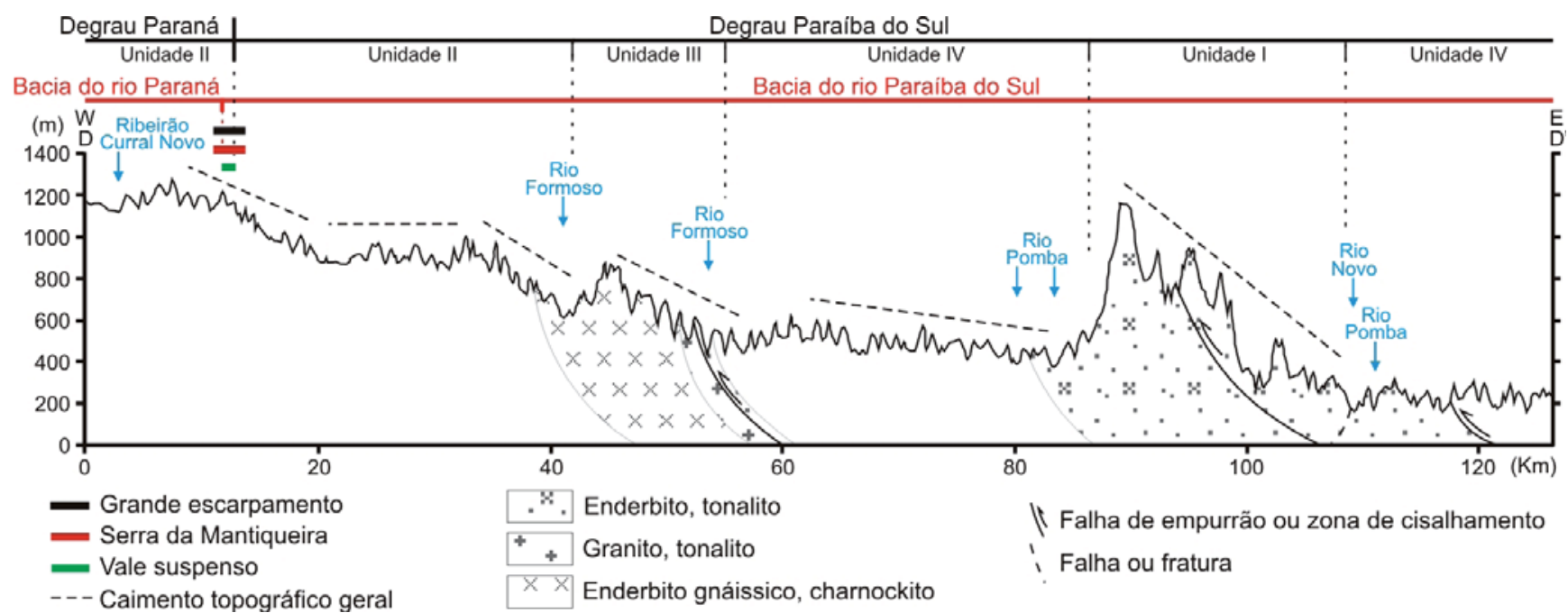

Figura 12 - Seção topográfica regional D-D’, em que se reconhecem os degraus Paraná - São Francisco e Paraíba do Sul.

\subsubsection{Unidade III - Degrau Paraíba do Sul}

Constitui uma unidade geomorfológica dissecada e escalonada, com cotas variando de 460 a $1240 \mathrm{~m}$. O relevo exibe formas alongadas com topos aguçados que se sobressaem na paisagem. Os vales tendem a ser pronunciados em virtude da maior incisão, gerando amplitudes que podem variar de 60 a 300m. A morfologia indica dissecação marcada por controle estrutural (Figuras 5 e 10).

As estruturas principais ocorrem nas direções NE-SW e E-W (Figura 4). Essas direções coincidem com as áreas de maior ampliação dessa unidade, sendo mais extensa a leste na direção NE-SW e a norte E-W. Em escalas de maior detalhe exibem controle NW-SE e N-S (Figuras 5 e 10). Essas estruturas também condicionam o rio Pomba, que assume direção ENE-WSW e a jusante se flexiona para NW-SE, cortando os granitos da Suíte Mercês-Ubari (Figuras 3 e 4).

Na porção NE da área ocorre uma diversidade de litologias associada a corpos intrusivos. Esses corpos intrusivos são comumente modelados em frentes escarpadas em razão da denudação diferencial (Figuras 3 e 4). A relação da topografia com as litologias sugere ainda a ocorrência de níveis de base locais que sustentam a 
porção montante e impedem a denudação mais agressiva dessas áreas (Figura 13). Cabe ressaltar que as porções de maior incisão fluvial nessas litologias coincidem com trechos sob forte condicionamento estrutural.

Nas escarpas limítrofes dessa unidade com os degraus adjacentes é comum a presença de vales suspensos (Figura 4), alcançando $450 \mathrm{~m}$ de altura a oeste e $300 \mathrm{~m}$ a NE. Esses vales ocorrem adjacentes a cursos fluviais estruturalmente controlados e em áreas onde a escarpa apresenta maior recuo. Contrastando com o restante da área, as porções norte e NW exibem escarpas escalonadas situadas entre $540-600 \mathrm{~m}$ a $720-900 \mathrm{~m}$ no primeiro patamar e 660-880m a 900-1160m no segundo, associadas a estruturas E-W e ENE-WSW (Figuras 5 e 10). Essas escarpas, em geral, exibem baixa sinuosidade que coincide com falhas e zonas de cisalhamento de mesma direção.

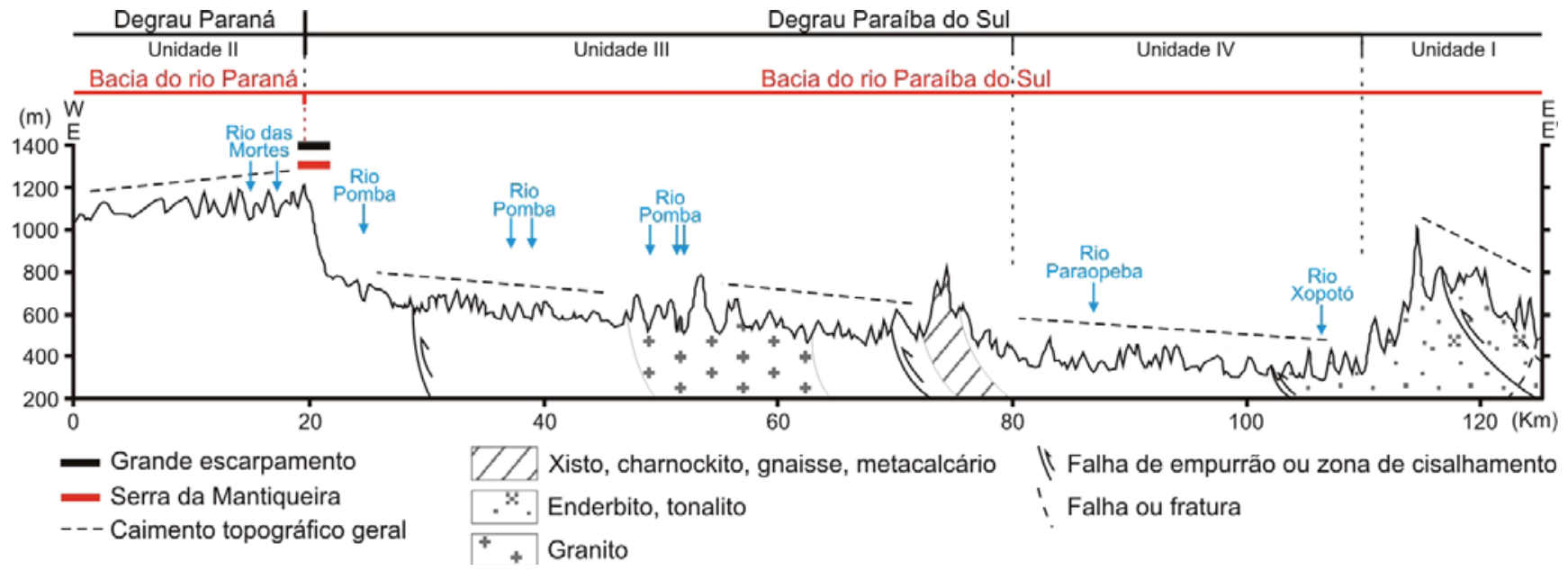

Figura 13 - Seção topográfica regional E-E’, em que se reconhecem os degraus Paraná - São Francisco e Paraíba do Sul.

\subsubsection{Unidade IV - Degrau Paraíba do Sul}

Constitui uma depressão escalonada, com altitudes entre 140 e $650 \mathrm{~m}$, podendo ser dividida de forma preliminar em quatro patamares. O primeiro, na região de Cataguases, varia de 140 a $400 \mathrm{~m}$ de altitude e a altura dos morros está entre 60 e $140 \mathrm{~m}$. O segundo se localiza entre os rios dos Bagres/Xopotó e o horst da Serra da Boa Vista - HSBV (Unidade I), com altitudes entre 320 a 380m e baixas colinas de topos convexos de até $40 \mathrm{~m}$ de altura. Esse constitui um vale entulhado por sedimentos aluviais, estando topograficamente rebaixado em relação ao seu entorno e suspenso em relação aos rios dos Bagres e Xopotó. O terceiro se encontra na região de Ubá, a NW da Unidade I e dos rios dos Bagres e Xopotó, com altitudes que variam entre 300 e $500 \mathrm{~m}$ e morros entre 80 e $120 \mathrm{~m}$ de altura. O quarto patamar apresenta altitudes entre 400 e $650 \mathrm{~m}$ e morros entre 40 e $140 \mathrm{~m}$ de altura, situando-se a oeste do HSBV, com início no divisor entre os rios Paraopeba e Pomba. Exceto pelo segundo patamar, no restante dessa unidade predomina relevo dissecado, representado por morros com topos variando de convexos a aguçados, o que confere aspecto mamelonar à paisagem.

As estruturas que predominam são de direção
NE-SW e, secundariamente, NW-SE, N-S e E-W (Figuras 3, 5 e 10). Essa unidade se alonga a NE-SW, em resposta às estruturas de mesma direção. No interior dessa unidade, essas estruturas condicionam, ainda, o caráter retilíneo da drenagem e inflexões bruscas, como nos rios dos Bagres, Pomba e Xopotó. O predomínio de estruturas NE-SW e a maior sinuosidade da escarpa nessa direção sugerem uma resposta denudacional do relevo ao condicionamento estrutural. Lineamentos neotectônicos mapeados por Morales et al. (2014) exibem ainda associação com o escalonamento em patamares, exceto pelo segundo, que indica ser proveniente de rochas mais friáveis do Complexo Paraíba do Sul.

O caimento topográfico geral ocorre para SE concordando com o caimento das demais unidades do Degrau Paraíba do Sul (Figura 12)e, segundo Noce et al. (2003), com a direção geral NW-SE da foliação. Exceção se verifica em pequena porção dessa unidade a NW, onde o caimento exibe o sentido NW (Figura 8). De acordo com Melo et al. (2005), esse escalonamento se estende do degrau da Serra da Mantiqueira até a Serra do Mar (Figura 11), marcado por estruturas NE-SW vinculadas a dois eventos tectônicos do Quaternário, um no Pleis- 


\section{Compartimentação Geomorfológica dos Planaltos Escalonados do Sudeste de Minas Gerais}

toceno Superior - Holoceno e, um outro, no Holoceno. Melo et al. (2005) admitem, ainda, uma tectônica mais antiga relacionada ao Rift Continental do Sudeste do Brasil como precursora do escalonamento verificado.

\section{Lineamentos Estruturais}

No Degrau Paraná - São Francisco a frequência e comprimento absolutos no diagrama de rosetas exibem direções principais dos lineamentos NE-SW, N-S e secundariamente NW-SE e E-W (Figura 14). A drenagem regional apresenta comportamento diferenciado em relação às bacias hidrográficas dos rios São Francisco e Paraná, cujos limites na área são concordantes também com uma diferenciação geotectônica, Cráton do São Francisco e Província Mantiqueira. Na bacia do rio São Francisco essas drenagens assumem direção preferencial N-S, enquanto que na bacia do rio Paraná NW-SE, NE-SW e E-W (Figura 4). Na bacia do rio São Francisco a drenagem regional (N-S) é concordante com direções N-S do diagrama de rosetas (Figuras 4 e 14). $\mathrm{Na}$ bacia do rio Paraná essa concordância ocorre na direção principal NE-SW e secundária NW-SE e E-W (Figuras 4 e 14).

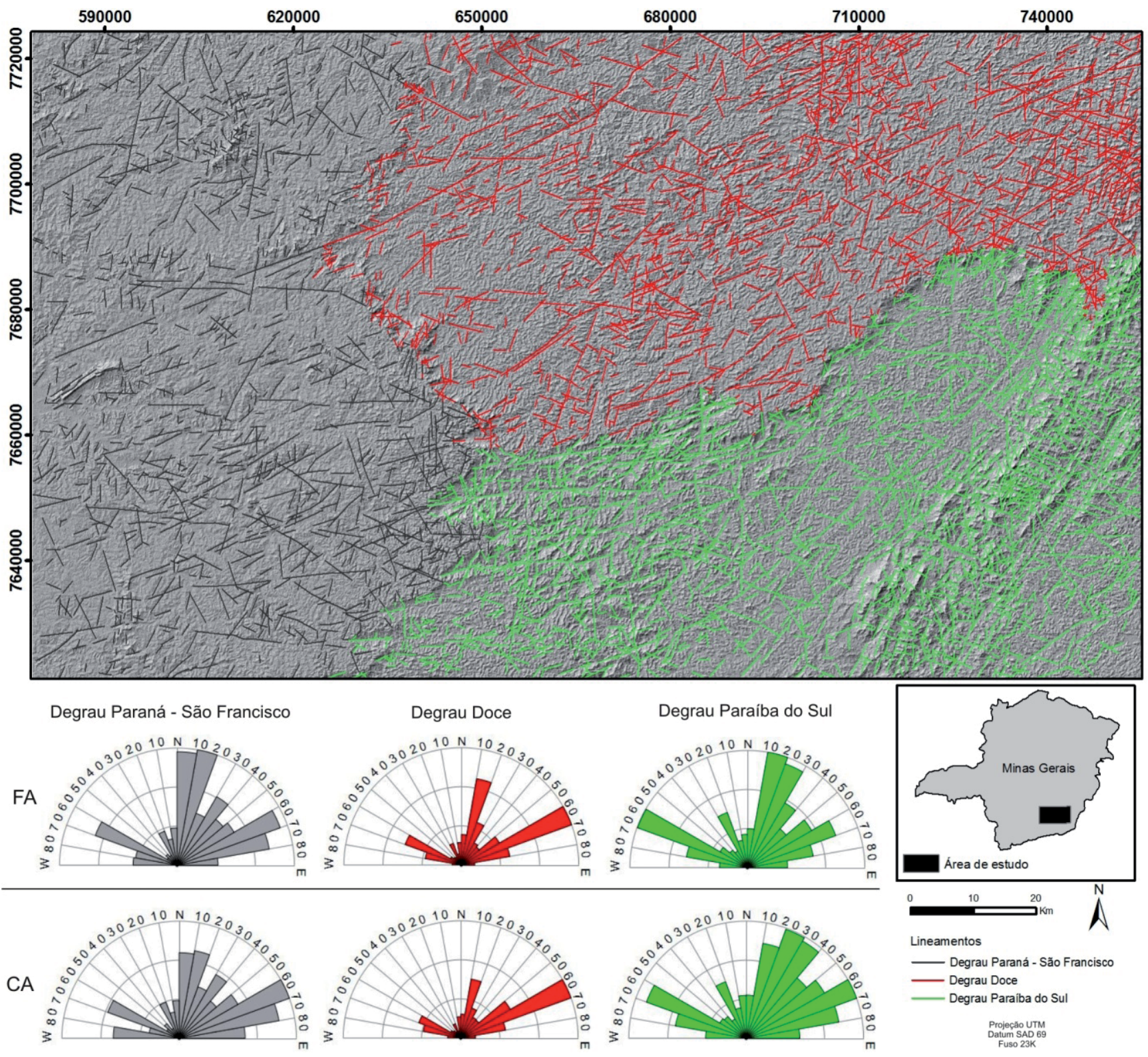

Figura 14 - Mapa e diagramas de roseta que representam a frequência acumulada (FA) e o comprimento acumulado (CA) dos lineamentos estruturais. 
No Degrau Doce a frequência e comprimento absolutos no diagrama de rosetas exibem direções principais dos lineamentos NE-SW e secundariamente NW-SE (Figura 14). A drenagem regional assume direções NE-SW, E-W, NW-SE e N-S (Figura 4). O controle estrutural detectado anteriormente sobre os principais cursos fluviais evidenciou uma correspondência com os lineamentos NE-SW (Figura 14). A direção NW-SE dos cursos fluviais encontra correspondência com a direção de lineamentos de mesma direção, mas que exibem menor destaque no diagrama de rosetas. Em relação à direção E-W de cursos fluviais submetidos a inflexões bruscas e a orientação N-S de alguns canais não houve uma correspondência de destaque com os lineamentos. As estruturas mapeadas em diferentes escalas, especificamente no contato desse compartimento com o Degrau Paraná - São Francisco, exibem direções NE-SW, NW-SE e E-W que coincidem com os maiores recuos na escarpa (Figura 4, 5 e 10). Isso indica uma evolução desses compartimentos comandados pela atuação dessas estruturas, que geram áreas mais susceptíveis à denudação pelo entalhamento do relevo.

No Degrau Paraíba do Sul a frequência e comprimento absolutos no diagrama de rosetas exibem direções principais dos lineamentos NE-SW e NWSE (Figura 14). A drenagem regional exibe direções NE-SW, NW-SE, E-W e N-S (Figura 4). O controle estrutural detectado anteriormente sobre os principais cursos fluviais evidenciou correspondência com os lineamentos NE-SW e NW-SE, enquanto os canais de orientação E-W e N-S exibiram correspondência secundária (Figura 4 e 14). As estruturas mapeadas em diferentes escalas, especificamente no contato desse compartimento com os degraus Paraná - São Francisco e Doce, exibem direções NE-SW, NW-SE e E-W que coincidem com os maiores recuos na escarpa (Figura 4, 5 e 10). Isso indica nas bordas desses compartimentos uma evolução comandada pela atuação dessas estruturas, que geram áreas mais susceptíveis à denudação pelo entalhamento do relevo.

Em todos os degraus os lineamentos adquirem direção NE-SW expressiva (Figura 14), concordante com estruturas regionais mapeadas em diferentes escalas, as quais refletem maior avanço das bacias hidrográficas nessa direção (Figura 4). As demais direções dos lineamentos NW-SE, N-S e E-W variam em cada degrau, mas exibem em geral um caráter secundário que se reflete em avanços menos expressivos nessas direções e em uma concordância com estruturas mapeadas em escalas menores (Figura 4, 5 e 10). A litologia representou um componente de controle local no recuo da escarpa (Figuras 4) e da geração de níveis de base com influências para a manutenção da paisagem em diferentes escalas (Figuras 6, 7, 8, 12 e 13), como por exemplo, na Unidade II - Degrau Paraíba do Sul (Figuras 3, 4 e 12). Nesse contexto, a diferenciação entre esses compartimentos constitui produto da denudação das bacias costeiras submetidas diretamente ao nível de base geral, mas com a evolução da rede de drenagem organizada segundo níveis de base locais e estruturas em diferentes escalas. Entretanto, em alguns perfis é possível identificar a morfologia regional dos escalonamentos em degraus controlada por falhas (Figura 8, 9 e 12). Essas falhas são identificadas nos mapeamentos geológicos como resultado de eventos de deformação compressiva relacionados aos ciclos Transamazônico e Brasiliano (Figura 3), enquanto a organização em degraus no relevo sugere cinemática de falhas normais condicionada a eventos distensivos do Cenozoico. Alguns perfis apresentam, ainda, a morfologia em degraus escalonados sem a presença de falhas (Figura 6 e 8), o que pode revelar baixa acuidade dos mapeamentos geológicos tendo em vista a escala em que foram elaborados. Essa análise sugere, portanto, um condicionamento morfológico regional à tectônica distensiva, responsável pelo caráter escalonado dos planaltos do sudeste de Minas Gerais.

\section{Considerações Finais}

Os procedimentos utilizados nesse trabalho reconhecem e caracterizam uma complexa trama espacial da organização geomorfológica de um trecho do sudeste de Minas Gerais, a qual se estrutura em degraus. No que se refere a essa organização, destacam-se:

(i) A compartimentação geomorfológica da área investigada se organiza, em planta e perfil, em um degrau superior (bacias dos rios Paraná - São Francisco), um intermediário (bacia do rio Doce) e, outro inferior (bacia do rio Paraíba do Sul). O que mais diferencia esses compartimentos é o desnível marcado por escarpas que coincide com a organização da rede hidrográfica regional, variando em média de 250 a 400m. Regionalmente, esses degraus apresentam características morfológicas tipicamente erosivas. Contudo, em algumas porções, a morfologia regional em degraus escalonados evidencia 
controle por falhas que indica também uma influência da tectônica cenozoica distensiva. Localmente, a litologia exerce controle sobre porções da escarpa e na configuração de subcompartimentos.

(ii) A morfologia regional é caracterizada por perfis que denotam caimento topográfico geral a NW, no caso dos degraus Paraná - São Francisco e Doce, e SE, no Degrau Paraíba do Sul. Esse caimento exibe inclinação e rebaixamento da superfície continuamente acentuados em direção ao interior das bacias hidrográficas, a partir de um setor de maior altimetria de direção NE-SW que coincide com a Serra da Mantiqueira. O caimento NW se apresenta concordante com a tectônica cenozoica, enquanto o SE sugere estar associado à tectônica e foliação da litologia que assume a mesma direção. O interior dos degraus mais extensos é marcado ainda pelo caimento de blocos menores que assumem a mesma tendência regional. Em alguns casos, a litologia assume o controle desse caimento que, por vezes, revela-se discordante do condicionamento estrutural regional.

(iii) As estruturas impõem um controle regional sobre a evolução da rede de drenagem, o que favorece a denudação de determinadas áreas e auxilia no estabelecimento de subcompartimentos geomorfológicos. Os recuos mais significativos dos escarpamentos se expressam por amplas concavidades regionais que avançam, em planta, continente adentro, em sentido SW, no Degrau Paraná - São Francisco. Há, porém, escarpamentos que avançam em sentido NE, em direção ao oceano. Ambos sentidos apresentam mesma direção estrutural NE-SW. O maior avanço da drenagem sobre as escarpas se apresenta ainda associado ao controle estrutural e exibe em planta elevada sinuosidade.

(iv) O controle litoestrutural exerce papel fundamental na gênese e dinâmica das anomalias de drenagem reconhecidas e mapeadas na área investigada. Algumas dessas anomalias estão associadas a vales suspensos, que expressam adaptações da rede hidrográfica ao processo de recuo das escarpas. Contudo, há trechos de algumas escarpas que coincidem com os divisores hidrográficos das bacias em que não se verifica a ocorrência de vales suspensos; nesse caso, o recuo à montante dos escarpamentos se faz mediante processos outros já discutidos por Bishop (1995), tal como aquele denominado beheading (decapitação).

\section{Agradecimentos}

Agradecemos ao subsídio da Coordenação de Aperfeiçoamento de Pessoal de Nível Superior (CAPES) mediante concessão de Bolsa de Doutorado ao primeiro autor, como também aos pareceristas anônimos que, pautados em rigorosos padrões de excelência científica, contribuíram fundamentalmente para o refinamento das ideias veiculas neste artigo.

\section{Referências Bibliográficas}

ALKMIM, F.F. O que faz de um cráton um cráton? O Cráton do São Francisco e as suas revelações Almeidianas ao delimitá-lo. In: MANTESSO-NETO, V.; BARTORELLI, A.; CARNEIRO, C.D.R.; BRITO-NEVES, B.B. Geologia do Continente SulAmericano: evolução da obra de Fernando Flávio Marques de Almeida. São Paulo: Beca, 2004. p. 17-35.

ALMEIDA, F.F.M. The system of continental rifts bordering the Santos Basin, Brazil. Anais da Academia Brasileira de Geociências, v. 48, p. 15-26 (suplemento), 1976.

BISHOP, P. Drainage rearrangement by river capture, beheading and diversion. Progress in Physical Geography, v. 19, n. 4, p. 449-473, 1995.

CHEREM, L.F.S.; VARAJÃO, C.A.C.; BRAUCHER, R.; BOURLÈS, D.; SALGADO, A.A.R.; VARAJÃO, A.C. O papel das capturas fluviais na morfodinâmica das bordas interplanálticas do sudeste do Brasil. Revista Brasileira de Geomorfologia, v. 14, n. 4, p. 299-308, 2013.

FERREIRA, M.F.M. Geomorfologia e análise morfotectônica do alto vale do Sapucaí - Pouso Alegre (MG). 2001. 276 f. Tese (doutorado) - Instituto de Geociências e Ciências Exatas, Universidade estadual Paulista, Rio Claro, 2001.

GATTO, L.C.S.; RAMOS, V.L.S.; NUNES, B.T.A.; MAMEDE, L.; GÓES, M.H.B.; MAURO, C.A.; ALVARENGA, S. M.; FRANCO, E. M. S.; QUIRICO A. F.; NEVES L. B. Geomorfologia. In: Projeto RADAMBRASIL. Folhas SF.23/24 Rio de Janeiro/Vitória. Rio de Janeiro: IBGE, 1983. p. 305-384.

GILCHRIST, A.R.; KOOI, H.; BEAUMONT, C. Post-Gondwana geomorphic evolution of southwestern Africa: implications for the controls on landscape development from observations and numerical experiments. Journal of Geophysical Research, v.99, n.B6, p. 12.211-12.228, 1994. 
GILCHRIST, A. R.; SUMMERFIELD, M. A. Differential denudation and flexural isostasy in formation of rifted-margin upwarps. Nature, v. 346, p.739-742, 1990.

GUNNELL, Y.; HARBOR, D.J. Butte detachment: how pre-rift geological structure and drainage integration drive escarpment evolution at rifted continental margins. Earth Surface Processes and Landforms, 35, p. 1373-1385, 2010.

HEINECK, C. A.; LEITE, C. A. S.; SILVA, M. A. da; VIEIRA, V. S. Mapa Geológico de Minas Gerais. Belo Horizonte, 2003. Convênio CPRM/COMIG. Escala 1:1.000.000.

MARENT, B.R.; SALGADO, A.A.R.; SANTOS, L.J.C. Modelos de elevação do relevo de margens passivas em regiões com Grande Escarpamento. Revista Brasileira de Geomorfologia, v. 14, n.2, p. 235-240, 2013.

MATMON, A.; BIERMAN, P.; ENZEL, Y. Pattern and tempo of great escarpment erosion. Geology, v. 30, n. 12, p. 11351138, 2002

MEIS, M.R.M.; MIRANDA, L.H.G,; FERNANDES, N.F. Desnivelamento de altitude como parâmetros para a compartimentação do relevo: bacia do médio-baixo Paraíba do Sul. In: CONGRESSO BRASILEIRO DE GEOLOGIA, 32., 1982, Salvador. Anais..., Salvador: SBG, v. 4, 1982, p. 1489-1503.

MELLO, C.L.; TOMAZ, E.A.; SILVA, R.C.B.; RODRIGUES, H.B. Condicionamento tectônico Cenozóico na evolução da depressão topográfica dos rios Pomba e Muriaé (MG, RJ). In: SIMPÓSIO NACIONAL DE ESTUDOS TECTÔNICOS, 10., 2005, Curitiba (PR). Boletim de resumos expandidos... Curitiba: [s.n.], v. 1, 2005. p. 192-194.

MORALES, N.; ALGARTE, K.T.S; ANTONIALLI, R.C.; ASSINE, M.L.; ASSUMPÇÃO, M.; BEZERRA, F.H.R.; BUENO, G.V.; ETCHEBEHERE, M.L.C.; M.L.C.; FERREIRA, J.M.; FONTES, S.L.; GOMES, L.C.C.; GONTIJO, R.C.; GONTIJO-PASCUTTI, A.H.F.; HASUI, Y.; LADEIRA, F.S.B.; NASCIMENTO, E.R.; NEVES, M.A.; SALAMUNI, E.; SILVA, C.L.; SOARES Jr., A.V.; SOUZA, I.A.; VINCENTELLI, M.G.C.; BRICALLI, L.L.; SOUSA, M.O.L. Projeto mapa neotectônico do Brasil: caracterização da deformação neotectônica do território brasileiro. In: CONGRESSO BRASILEIRO DE GEOLOGIA, 47, 2014, Salvador. Anais..., Salvador: SBG, 2014, p. 851.

NOCE, C.M.; ROMANO, A.W.; PINHEIRO, C.M.; MOL, V.S.; SOARES, A.C.P. Geologia das Folhas Ubá e Muriaé. In: PEDROSA-SOARES, A. C.; NOCE, C.M.; TROUW, R. A. J.; HEILBRON, M. Geologia e recursos minerais do sudeste mineiro: Volume III. Projeto Sul de Minas-Etapa I (COMIGUFMG-UFRJ-UERJ), COMIG, 2003. p. 623-659.

OLLIER, C.D.; PAIN, C.F. Equating the basal unconformity with the palaeoplain: a model for passive margins. Geomorphology, 19, p. 1-15, 1997.

RAPOSO, F.O. Programa de Levantamentos Geológicos Básicos do Brasil. Folha Rio Espera - texto explicativo. Escala 1:100.000. Org. RAPOSO, F.O. Belo Horizonte, DNPM-CPRM, 1991. 200 p.

SAADI, A. Ensaio sobre a morfotectônica de Minas Gerais (tensões intraplacas, descontinuidades crustais e morfogênese). 1991. 285 f. Tese para professor titular - Instituto de Geociências, UFMG, Belo Horizonte, 1991.

SILVA, T.M. Estruturação geomorfológica do Planalto Atlântico do Estado do Rio de Janeiro. 2002. 269 f. Tese (Doutorado) - Universidade Federal do Rio de Janeiro, 2002.

SOUZA, C.J. Interpretação morfotectônica da bacia do Rio Doce. 1995. 146 f. Dissertação (Mestrado) - Instituto de Geociências, Universidade Federal de Minas Gerais, 1995.

VALADÃO, R. C. Evolução de longo termo do relevo do Cráton do São Francisco (denudação, paleosuperfícies e movimentos crustais). 1998. 343 f. Tese (Doutorado) - UFBA, Salvador, 1998.

VAN BER BEEK, P.; SUMMERFIELD, M.A.; BRAUN, J.; BROWN, R.W.; FLEMING, A. Modeling postbreakup landscape development and denudational history across the southeast African (Drakensberg Escarpment) margin. Journal of Geophysical Research, v. 107, n. B12: 2351, 2002.

ZALÁN, P.V.; OLIVEIRA, J.A.B. Origem e evolução estrutural do sistema de riftes cenozóicos do Sudeste do Brasil. Boletim de Geociências da Petrobrás, v. 13, n. 2, p. 269-300, 2005. 